\title{
子どものIT 機器の使い方評価シートと活用事例
}

\author{
阿久津正大 ${ }^{1}{ }^{2}$, , O伊藤由香里 ${ }^{2}$ \\ ${ }^{1}$ 玉川大学工学部, ${ }^{2}$ 子どものための快適 IT 環境づくり研究会 \\ Check-sheet for Children's Usage of IT and the Case Study \\ Masahiro Akutsu, ${ }^{1,2}$, Yukari Ito ${ }^{2}$ \\ ${ }^{1}$ Faculty of Eng., Tamagawa Univ., ${ }^{2}$ Research Group on IT-use for Children
}

\section{1. はじめに}

子どもの IT (Information Technology) 利用が学 校や家庭で急速に広まっている。インターネット に代表される IT の利用は学習の効率化などに多 大な貢献をしているが、一方で視力や調節力など の視機能や、自律神経系、脳機能の成長など、子 どもたちの心身の健全な発育に深刻な影響をお よぼす面も有している。IT 機器の使い方が悪い場 合には、人間工学的対策を講じる必要がある。

そのためには、子ども各人の IT 機器の使い方 の良悪を把握しなければならない。そこで著者ら は、保護者が簡単なチェックによって、子どもの IT 機器の使い方の良悪を把握することができる 評価シートを開発した ${ }^{1)}$ 。

本報では開発した評価シートを使用して、多数 の小学児童における家庭内での IT 機器の使用上 の良悪を評価し、さらに評価シートの有用性につ いて検証を試みた事例を紹介する。

\section{IT 機器の使い方評価シート}

一部改良を加えた最新の評価シートを図 1 に示
す。テレビ・ゲーム機・パソコンなどの IT 機器 の使い方に係わる 18 項目について、5段階 $(2 \sim-2$ 点)で評価してゆき、総平均点より使い方の良悪 の総合レベル「まったく安心」「安心」「やや危険」 「かなり危険」「非常に危険」を判定することが できる。評価シートは、子どもの IT 機器の使用 状況を観察しながら短時間でチェックでき、使い 方の良悪の総合判定だけでなく、18 項目にわたり 問題の所在を把握することができる。また改善の 方向がわかるようになっている。

\section{3. 家庭での小学児童の IT 機器の使い方の調查}

\section{3-1 調查概要}

横浜市立 $\mathrm{K}$ 小学校の保護者 430 名に、評価シー 卜を用いて、平日と休日 1 日ずつ、子どもの IT 機器の使い方の評価を依頼した。加えて評価シー トの有用性、不備な点などを試用評価アンケート により尋ねた。評価実施期間は平成 17 年 12 月 10 日（土） 18 日（日）までの 10 日間であった。 評価シートの有効回答率は、平日の評価 $41.2 \%$ (177 名回収)、休日の評価・試用評価アンケート

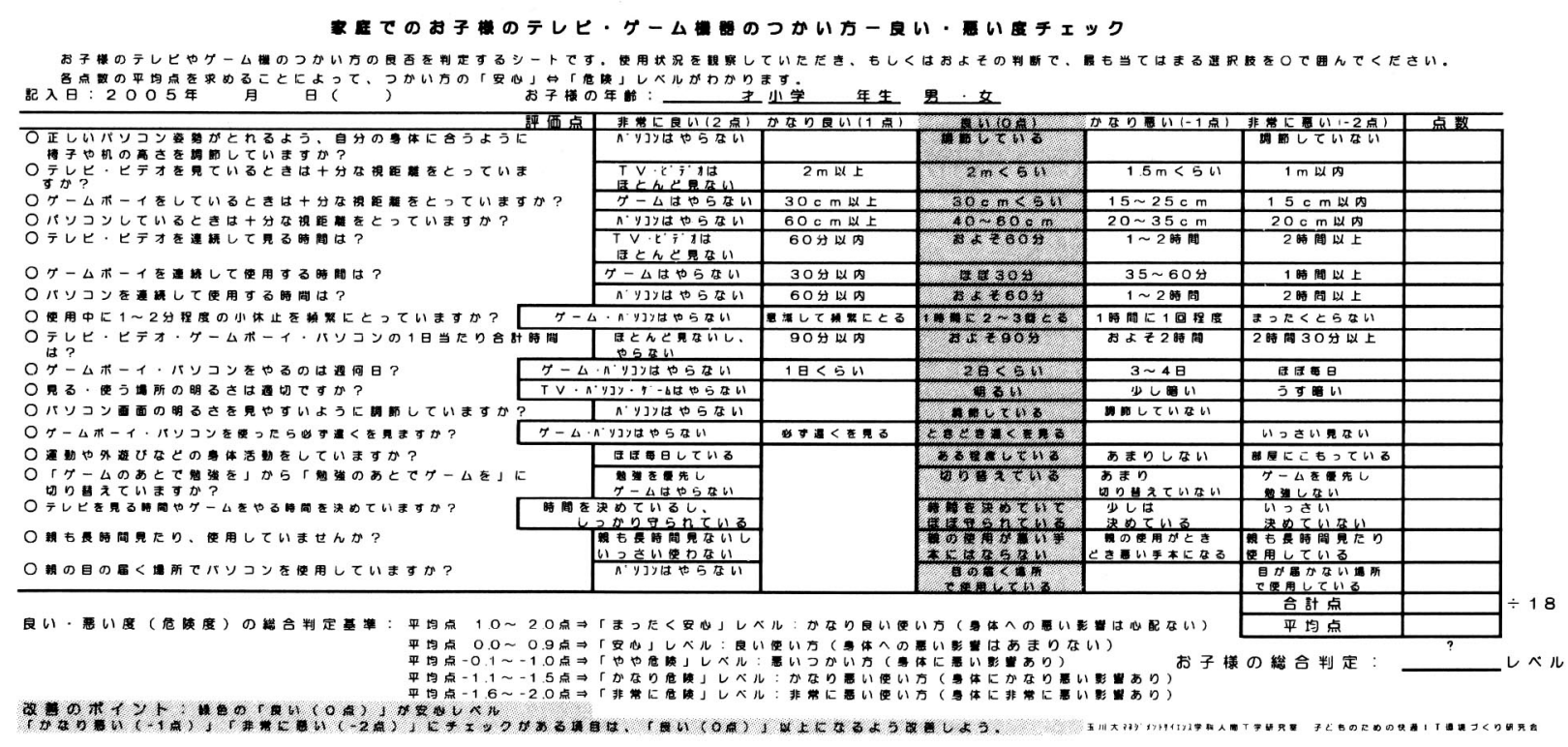

図 1 開発した IT 機器の使い方評価シート 
ともに 40.9\%(176 名回収)であった。

\section{3-2 児童全体の使い方の判定結果}

児童全体 (1 6 年生)の IT 機器の使い方の判定 結果は、平日・休日で同じ割合となり、「まった く安心」19\%、「安心」54\%、「やや危険」26\%、「か なり危険」 $1 \%$ 、「非常に危険」 $0 \%$ あった。使い 方を見直す必要がある児童がおよそ 4 人に 1 人 (27\%)いることがわかった（表 2)。

\section{3-3 学年別にみた判定結果}

使い方が「やや危険」「かなり危険」と判定さ れた児童の割合は、学年が上がるにつれて増えて いた。3 年生までは「やや危険」の割合が $20 \%$ 以 下であるが、 4 年生以上では、「かなり危険」な使 い方をしている児童もみられ、「やや危険」十「か なり危険」の割合は 30〜40\%台であった。人間工 学的配慮を必要な児童は 4 年生以上に多い(表 2)。

\section{3-4 男女別にみた判定結果}

「やや危険」十「かなり危険」の割合は、男子 28〜29\%、女子 25\%であった。使い方が悪い児童は 女子よりも男子が少し多かったが、男女で大差は なかった。使い方がよい(「まったく安心」)と判 定された割合は女子が男子の 2 倍多かった (表 3 )。

\section{3-5 全体的に悪い使い方の項目}

図 2 は、平日における児童全体の IT 機器の使 い方 18 項目についての平均得点と SD を示す。得 点の傾向は、平日と休日で大きな違いはない。多 くの児童が悪い使い方をしている項目 $(0$ 点未満 の項目)は、項目 2 「テレビ・ビデオを見ていると きの視距離(見る距離が近い)」、項目 5 「テレビ・ ビデオを連続して見る時間の長さ (やる時間が長 い)、項目 9 「テレビ・ビデオ・ゲーム機・パソ コンの 1 日当りの合計時間(時間が長い)」、項目 10 「ゲーム機・パソコンをやる週当りの日数(や る日数が多い)、項目 13 「ゲーム機・パソコンを 使ったら必ず遠くを見る(遠くを見ない)」。項目 16「テレビを見る時間やゲームをやる時間を決め ている(決めていない)」であった。

\section{3-6 試用評価アンケートの結果}

「評価シートの有効性」については、有効と思 う $54 \%$ 、どちらともいえない $39 \%$ 、有効ではない 7\%であった。「評価シートが使い方の指導に役立 つか」については、役立つ 60\%、どちらともいえ ない $34 \%$ 、役立たない $6 \%$ であった「評価シート の使用により IT 機器の使い方に対する配慮の大 切さの認識が高まるか」については、高まる $56 \%$ 、
表 2 学年別にみた IT 機器の使い方の判定結果

\begin{tabular}{|c|c|c|c|c|c|c|c|c|}
\hline & . & 平均 & 標淮㴜 & 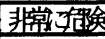 & 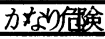 & 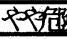 & 安心 & まsたく安心 \\
\hline 种生 & 29 & 076 & 0.73 & $0 \%$ & $0 \%$ & $12 \%$ & $49 \%$ & $44 \%$ \\
\hline & 28 & 060 & 0.74 & $0 \%$ & $0 \%$ & $18 \%$ & $41 \%$ & $41 \%$ \\
\hline 的平 & 2 & 0.37 & 0.48 & $0 \%$ & $0 \%$ & $16 \%$ & $72 \%$ & $12 \%$ \\
\hline & क & 0.33 & 0.47 & $0 \%$ & $0 \%$ & $12 \%$ & $70 \%$ & $12 \%$ \\
\hline 平 & 27 & 0.34 & 0.46 & $0 \%$ & $0 \%$ & $19 \%$ & $74 \%$ & $7 \%$ \\
\hline & 27 & 0.35 & 0.55 & $0 \%$ & $0 \%$ & $13 \%$ & $7 \%$ & $10 \%$ \\
\hline$=\bar{x}$ & 35 & 026 & 0.74 & $0 \%$ & $0 \%$ & $29 \%$ & $51 \%$ & $20 \%$ \\
\hline 休 & 34 & 0.21 & 0.73 & $0 \%$ & $3 \%$ & $32 \%$ & $44 \%$ & $21 \%$ \\
\hline & 32 & 0.09 & 0.6 & $0 \%$ & $0 \%$ & $4 \%$ & $40 \%$ & $13 \%$ \\
\hline 休E & 32 & 0.01 & 0.60 & $0 \%$ & $0 \%$ & 44\% & $47 \%$ & $9 \%$ \\
\hline 平 & 29 & 0.17 & 0.70 & $0 \%$ & $3 \%$ & $32 \%$ & $48 \%$ & $17 \%$ \\
\hline 休 & 29 & 0.28 & 0.80 & $0 \%$ & $3 \%$ & $31 \%$ & $45 \%$ & $21 \%$ \\
\hline 本平 & 177 & 0.31 & 0.67 & $0 \%$ & $1 \%$ & $20 \%$ & 5 徒 & $19 \%$ \\
\hline 休日 & 176 & $0: \mathbb{B}$ & 0.67 & $0 \%$ & $1 \%$ & $20 \%$ & $54 \%$ & $19 \%$ \\
\hline
\end{tabular}

表 3 判定結果の男女比較

\begin{tabular}{|c|c|c|c|c|c|c|c|c|}
\hline & $\underline{n}$ & \multicolumn{2}{|c|}{ 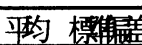 } & \multicolumn{5}{|c|}{ 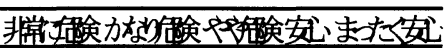 } \\
\hline 男平何 & 94 & 018 & 06 & $\%$ & $\mathrm{P}$ & $2 \%$ & $59 \%$ & $14 \%$ \\
\hline 休目 & $\mathscr{Q}$ & 015 & 065 & \% & $\mathrm{p} \%$ & $2 \mathbb{2} \%$ & $5 \%$ & $14 \%$ \\
\hline 好平目 & 79 & 036 & 069 & Q & $\%$ & $2 \%$ & $59 \%$ & 24 \\
\hline 休目 & 80 & 0.37 & Q69 & \% & $\mathbb{1}$ & 20\% & $5 \%$ & $2 \%$ \\
\hline
\end{tabular}

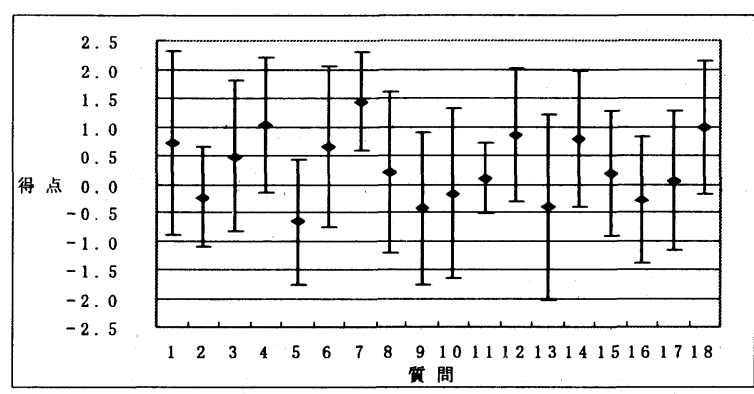

図 2 平日における IT 機器の使い方の項目別得点

どちらともいえない $33 \%$ 、高まらない $11 \%$ あっっ た。有用性を肯定する回答が半数以上より得られ た。

\section{4. まとめ}

開発した評価シートを使用し、多数の小学児童 における家庭での IT 機器の使用上の良悪の評価 を試みた。使い方を見直したい児童が 4 人に一人 いること、そうした児童は 4 年生以上で多いこと、 18 項目にわたる使い方の児童全体の状況、につい て明らかにできた。また、試用アンケートにより 評価シートの有用性を確認できた。

\section{参考文献}

1) 阿久津正大, 伊藤由香里: 子どもの IT 機器の使い方評 価シートの開発, 人間工学, 第 41 巻特別 号, 310-311, 2005 